\title{
Nickel induces secretion of IFN- $\gamma$ by splenic natural killer cells
}

\author{
Ji-Yeon Kim ${ }^{1}$, Kyungmin Huh", \\ Ki-Young Lee ${ }^{1}$, Jun-Mo Yang ${ }^{2}$ \\ and Tae Jin Kim ${ }^{1,3}$ \\ 'Division of Immunology \\ Department of Molecular Cell Biology and \\ Samsung Biomedical Research Institute \\ Sungkyunkwan University School of Medicine \\ Suwon 440-746, Korea \\ ${ }^{2}$ Department of Dermatology \\ Sungkyunkwan University School of Medicine \\ Samsung Medical Center \\ Seoul 135-710, Korea \\ ${ }^{3}$ Corresponding author: Tel, 82-31-299-6161; \\ Fax, 82-31-299-6179; E-mail, tjkim@ @kku.edu \\ DOI 10.3858/emm.2009.41.4.032
}

\section{Accepted 1 December 2008}

Abbreviations: CDR, complementary determining region; ELISPOT, enzyme-linked immunosorbent spot; NK cell, natural killer cell; RAG, recombination activating gene; SPF, specific pathogen-free; Th1, $\mathrm{T}$ helper 1

\begin{abstract}
Although nickel hypersensitivity is known as a delayed-type hypersensitivity mediated by nickel-specific $T$ cells, it is greatly influenced by other immune cells. Here we show that splenic natural killer cells (NK cells) directly or indirectly respond to nickel by secretion of IFN- $\gamma$. Using enzyme-linked immunosorbent spot (ELISPOT) assays, we found that nickel-reactive cells readily secreted IFN- $\gamma$ when splenocytes were cultured in the presence of varying concentrations of nickel sulfate $\left(\mathrm{NiSO}_{4}\right)$ for $24 \mathrm{~h}$. However, nickel-reactive IL-2- or IL-4-secreting cells were infrequent during the 24-h culture with $\mathrm{NiSO}_{4}$. Immune responses to nickel were innate, not adaptive, in nature since the frequency of nickel-reactive IFN- $\gamma$-secreting cells did not increase upon previous exposure to $\mathrm{NiSO}_{4}$ and recombination activating gene (RAG)-1-deficient mice contained nickel-reactive IFN- $\gamma$-secreting cells. The involvement of $\mathrm{NK}$ cells in the innate response to $\mathrm{NiSO}_{4}$ was confirmed since we could observe a significant reduction of the frequency of nickel-reactive cells in NK cell-depleted mice. Furthermore, the number of IFN- $\gamma$ secreting cells was significantly reduced in the ELISPOT assays when NKG2D was blocked by anti-NKG2D
\end{abstract}

antibody. These results suggest that there is an early and rapid innate immune response to nickel, which is mediated by NK cells and the NKG2D receptor. The significance of the innate response to nickel is that it may contribute to development of the late T cell-mediated delayed type hypersensitivity against nickel.

Keywords: hypersensitivity; immunosorbent techniques; interferon- $\gamma$; killer cells, natural; nickel; NK cell lectin-like receptor subfamily $\mathrm{K}$

\section{Introduction}

Nickel is commonly found in coins, jewelry, and many other surrounding materials, but nickel is the most common occupational as well as environmental contact allergen (Basketter et al., 1993; Zug et al., 2008). Nickel in metal prostheses used in orthopedic, dental, and other surgeries may also cause immune responses to nickel, preventing the patients from successfully maintaining the prosthesis (Saglam et al., 2004; Hallab et al., 2005). In contact with biological system, nickel metal corrodes and releases nickel ions, the most common and stable form of which is $\mathrm{Ni}^{2+}$ and is mostly present as $\mathrm{NiCl}_{2}$ or $\mathrm{NiSO}_{4}$, the nickel salts commonly used in the study of nickel allergy. About $20 \%$ of people show the immune responses to nickel ions in the skin patch test and some of them clinically develop nickel contact dermatitis (Mortz et al., 2001; Schafer et al., 2001; de Waard-van der Spek and Oranje, 2008).

The immunological mechanisms underlying the allergic response to nickel are not well known, but the formation of metal-protein complexes are considered to elicit immune responses since a nickel ion is too small to be specifically recognized by $T$ and $B$ cell antigen receptors or immune receptors. Similarly to chemical haptens, metal ions interact with proteins and then become recognizable by $T$ and B lymphocytes (Budinger and Hertl, 2000; Martin, 2004). Whereas the description of nickelspecific antibodies is rare probably due to the diversity of proteins conjugated to nickel ion, several groups reported the presence of nickel-specific $T$ cells (Kapsenberg et al., 1987; Silvennoinen-Kassinen et al., 1991; Sebastiani et al., 2002; Gamerdinger et al., 2003). Those nickel-specific $\mathrm{CD}^{+}$ and $\mathrm{CD} 8^{+} \mathrm{T}$ cells may explain the immunological pathogenesis of nickel contact dermatitis and immune response to nickel-containing metal im- 
plants since nickel-specific $\mathrm{T}$ cells have been repeatedly detected in sensitized human and animals. The immune response to nickel is regarded as an example of delayed type hypersensitivity model, especially if nickel was applied subcutaneously (Ishii et al., 1995).

However, it is still not clear how initial immune responses to nickel can appear before the generation of nickel-reactive memory $T$ cells. To avoid inappropriate immune responses to self components, the induction of $\mathrm{T}$ cell immune response requires preceding innate immune responses to invading microorganisms or tissue damages (Kroczek et al., 2004). Innate immune responses against pathogen- or danger-associated molecular patterns provide costimulatory signals to antigenspecific T cells (Matzinger, 2002; Akira et al., 2006), but if the costimulatory signals are not sufficient, antigen-specific $T$ cells do not respond or are switched to become tolerant (Hawiger et al., 2004; Goodnow et al., 2005). To the best of our knowledge, there were no reports that showed innate immune responses against metal ions. In fact, the nickel allergy was difficult to be established in the mouse model and could be more efficiently induced by the concomitant administration of lipopolysaccharide, a bacterial molecular pattern molecule (Sato et al., 2007). In the current study, we intended to measure nickel-responsive $T$ cells in the mouse spleen by using enzyme-linked immunosorbent spot (ELISPOT) analyses and unexpectedly found that there were a lot of nickel- reactive IFN- $\gamma$ secreting cells among splenic cells even in the non-immunized mice. We further investigated the nature of nickel-reactive cells and provided evidences that they included natural killer cells (NK cells) by depleting NK cells or blocking a representative NK receptor, NKG2D.

\section{Results}

\section{Abundant nickel-responsive IFN- $\gamma$ secreting cells in mouse spleen}

To investigate the nickel hypersensitivity, we first assessed the frequencies of nickel-reactive cells among splenocytes from untreated 6 week-old C57BL/6 mice by ELISPOT assay. Since the ELISPOT assay was performed by $24-\mathrm{h}$ stimulation with $\mathrm{NiSO}_{4}$ and naive $\mathrm{T}$ cells usually require at least a few days for immune response, it was expected that only memory nickel-reactive T cells could respond to nickel ions and secrete cytokines. We measured the numbers of IL-2-, IL-4-, and IFN- $\gamma$-secreting cells since $\mathrm{T}$ cells participating in the immune response to nickel could be either Th1 or Th2 cells (Artik et al., 2001; Sebastiani et al., 2002). Total splenic cells were isolated and then 1 $\times 10^{5}$ cells were cultured in each well of ELISPOT plates with complete RPMI 1640 media and varying concentrations of $\mathrm{NiSO}_{4}$ for $24 \mathrm{~h}$. Contrary to our expectation, a high frequency of nickel-reactive cytokine-secreting cells were detected upon $\mathrm{NiSO}_{4}$ stimulation in non-sensitized mice (Figure 1). Although there were IL-2- or IL-4-secreting cells in the spleen, the IFN- $\gamma$-secreting cells outnumbered IL-2- or IL-4- secreting cells. The number of IFN- $\gamma$-secreting cells increased in a concentrationdependent manner as we assayed with increasing concentrations of $\mathrm{NiSO}_{4}$. Whereas the numbers of IL-2- or IL-4-secreting cells decreased in high

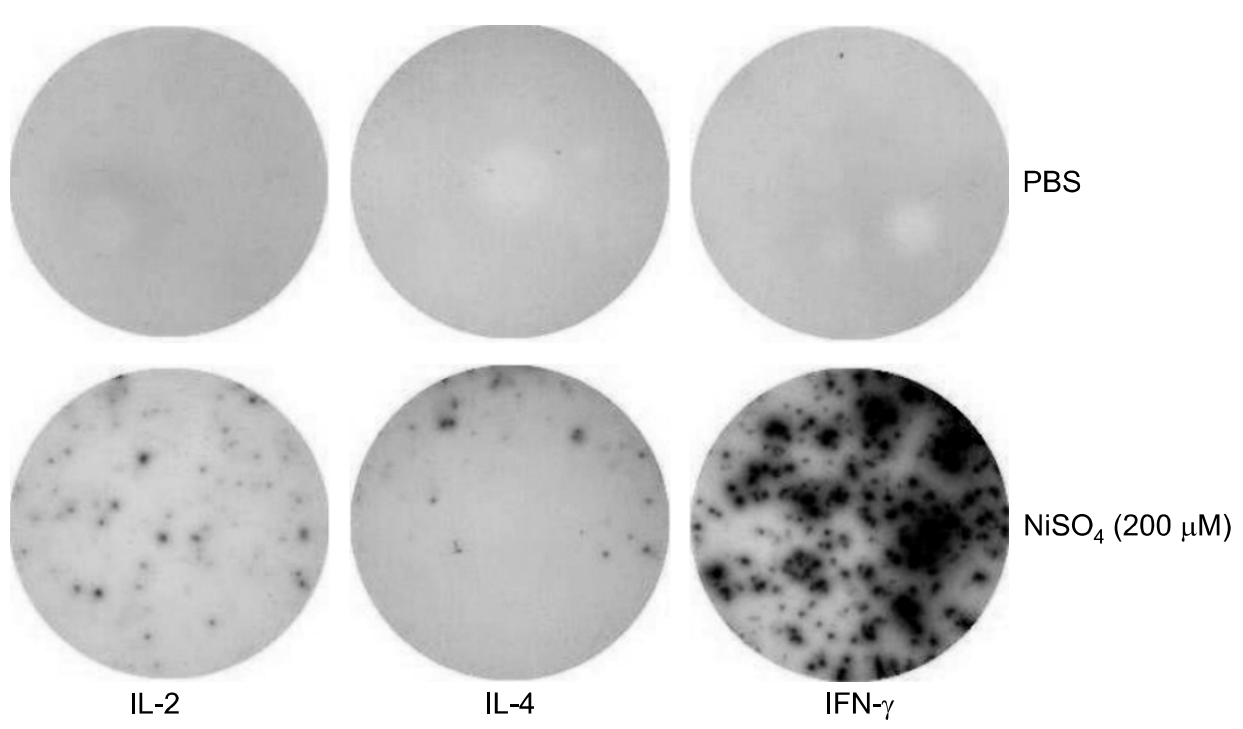

Figure 1. A high frequency of nickel-responsive cells in mouse spleen. Single cell resolution of nickel-induced IL-2, IL-4, and IFN- $\gamma$ production in freshly isolated splenic cells as verified by measuring cytokine production using the ELISPOT assay. Each well was coated with given anti-cytokine antibodies, plated with $1 \times 10^{5}$ spleen cells, and incubated for $24 \mathrm{~h}$ in the presence of $200 \mu \mathrm{M} \mathrm{NiSO}$. Each cytokine-secreting cells were visualized by the biotinylated cytokine detection antibody, streptavidin-HRP, and HRP substrate. 
concentrations of $\mathrm{NiSO}_{4}(\geq 400 \mu \mathrm{M})$, the number of IFN- $\gamma$-producing cells remained high in high concentrations of $\mathrm{NiSO}_{4}$ (Figure 2). We could observe more than 100 IFN- $\gamma$-secreting cells per 1 $\times 10^{5}$ cells when splenocytes were cultured in the concentration of $\mathrm{NiSO}_{4} \geq 200 \mu \mathrm{M}$.

With these results, we hypothesized that nickelreactive cells might be innate immune cells such as NK cells and $\gamma \delta \mathrm{T}$ cells, since they have a feature of memory lymphocytes and are responding to given antigens without previous sensitization. Especially, we paid attention to IFN- $\gamma$-secreting cells, which might be early-reacting NK cells.

\section{No increase in the number of IFN- $\gamma$-secreting cells upon previous immunization of $\mathrm{NiSO}_{4}$}

The presence of a high frequency of IFN- $\gamma$ secreting cells in the spleen from mice grown in the SPF condition without any previous exposure to $\mathrm{NiSO}_{4}$ suggested that these cells might be innate cells. If they are innate cells, it is highly likely that the frequency of IFN- $\gamma$-secreting cells do not increase upon previous immunization of $\mathrm{NiSO}_{4}$. Therefore, we next estimated the number of nickelreactive IFN- $\gamma$-secreting cells in the spleens from $\mathrm{NiSO}_{4}$-immunized mice. 6-week-old C57BL/6 mice were immunized with $300 \mu \mathrm{l}$ of $10 \mu \mathrm{M} \mathrm{NiSO}_{4}$ admixed with alum. We assessed the frequency of nickelreactive IFN- $\gamma$-secreting cells in the spleens removed 2 weeks or 4 weeks after the immunization (Figure 3; results of immunization for 2 weeks shown). As compared to normal mouse controls, the number of nickel-reactive IFN- $\gamma$-secreting cells

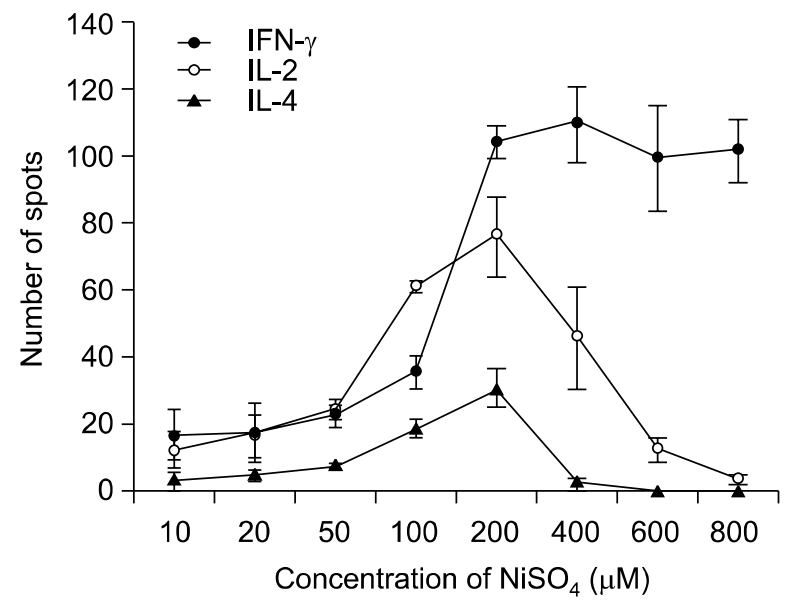

Figure 2. Increased frequency of nickel-responsive cytokine-secreting cells with increasing concentrations of $\mathrm{NiSO}_{4}$. Splenocytes from 6-week-old $\mathrm{C} 57 \mathrm{BL} / 6$ mice were incubated for $24 \mathrm{~h}$ with various concentrations of $\mathrm{NiSO}_{4}$. Using ELISPOT assay, the number of IL-2-, IL-4-, and IFN- $\gamma$-secreting cells was evaluated by counting the number of spots. did not significantly increase in mice immunized with $\mathrm{NiSO}_{4}$ for either 2 or 4 weeks. These findings further support that nickel-reactive IFN- $\gamma$-secreting cells shown in naive mice are innate cells and that they are not expanding upon the exposure to $\mathrm{NiSO}_{4}$.

\section{IFN- $\gamma$-secreting cells are also seen in RAG-1-deficient mice and reduced in number by depletion of NK cells}

Although nickel-reactive IFN- $\gamma$-secreting cells had characteristics of innate cells, there is still a possibility that they may be innate T cells such as NKT cells, $\gamma \delta \mathrm{T}$ cells or intraepithelial $\mathrm{T}$ cells. Since these innate $T$ cells are absent from recombination activating gene (RAG)-1-deficient mice, we assessed nickel-reactive IFN- $\gamma$ - secreting cells in spleens from RAG-1-deficient mice (Figure 4). As shown in Figure 4B, we could observe that RAG-1-deficient mice contained nickel-responsive cells similarly to wild type mice. In the RAG-1-deficient mice, the number of nickel-reactive IFN- $\gamma$-secreting cells decreased with increasing concentrations of $\mathrm{NiSO}_{4}$ in contrast to wild type mice. However, the presence of nickel-reactive IFN- $\gamma$-secreting cells in RAG-1deficient mice confirms that IFN- $\gamma$-secreting cells are innate cells, which develop independently of gene rearrangement. To delineate the type of innate cells that secrete IFN- $\gamma$ in response to nickel further, we performed NK cell depletion experiments using anti-NK1.1 antibody. After scheduled injections of anti-NK1.1 antibody, we checked the frequency of nickel-reactive IFN- $\gamma$-secreting cells by the ELISPOT assay and confirmed partial depletion of NK cells by a flow cytometric analysis (Figure 4A). We could observe a dramatic decrease in the number of IFN- $\gamma$ spots when spleen cells from NK cell depleted mice were used (Figure 4B). These results

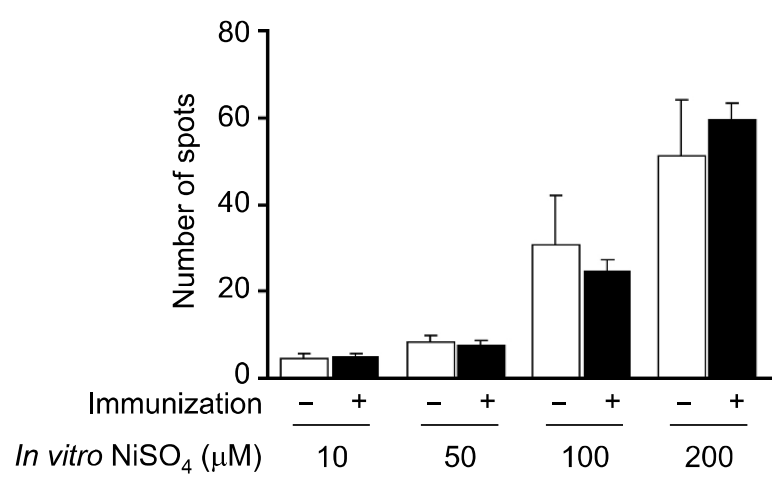

Figure 3. Nickel-responsive IFN- $\gamma$-secreting cells do not have a memory. C57BL/6 mice were immunized with $10 \mu \mathrm{M} \mathrm{NiSO}_{4}$ plus adjuvant. 2 weeks later, splenocytes were harvested and incubated for $24 \mathrm{~h}$ with indicated concentrations of $\mathrm{NiSO}_{4}$ and the number of IFN- $\gamma$-secreting cells was counted using the ELISPOT assay. 
A

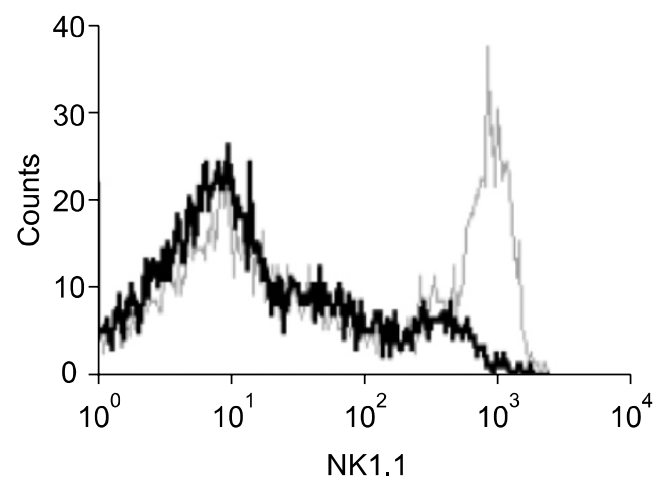

B

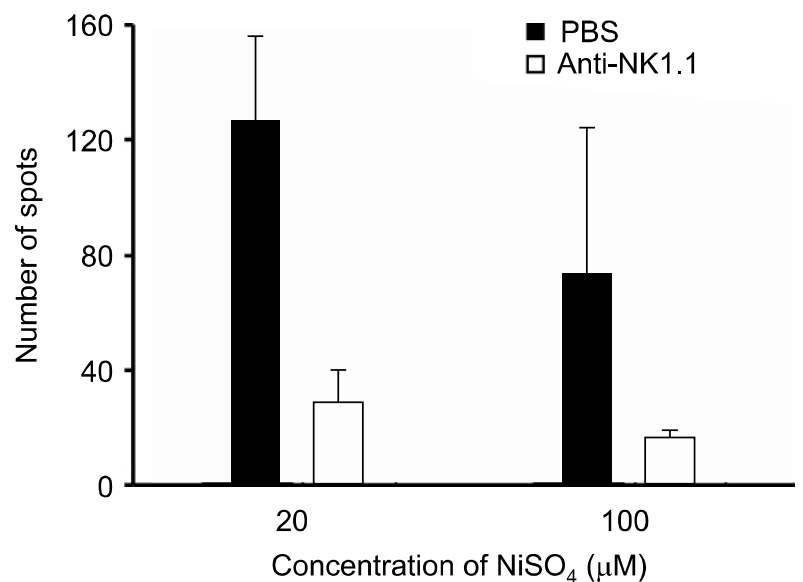

Figure 4. IFN- $\gamma$-secreting cells are abolished by depletion of NK cells in RAG-1-deficient mice. $25 \mu \mathrm{g}$ of anti-NK1.1 antibody dissolved in $300 \mu$ I PBS were administered intraperitoneally to RAG-1-deficient mice on days 2, 5, and 8 before analysis. (A) A flow cytometric analysis with splenocytes stained for NK1.1. Data of cells in the small lymphocyte gate show $>90 \%$ reduction of NK1.1+ cells after anti-NK1.1 antibody treatment (Thin, before treatment; Thick, after treatment). Please note that NK cells are abundant in RAG-1-deficient mice since they are lacking in T and B lymphocytes. (B) Splenocytes from control and NK cell-depleted RAG-1-deficient mice were harvested and incubated for $24 \mathrm{~h}$ with indicated concentrations of $\mathrm{NiSO}_{4}$. The number of IFN- $\gamma$-secreting cells was counted by the ELISPOT assay.

clearly show that NK cells are responsible for the response to nickel although the participation of other types of cells such as dendritic cells or macrophages cannot be excluded.

\section{IFN- $\gamma$-secreting cells are diminished by blocking of NKG2D in RAG-1-deficient mice}

NK cells possess many kinds of activating and inhibitory receptors and thus it is very difficult to find the molecular entity responsible for sensing the presence of small nickel ions or nickel-protein complexes. We assumed that the presence of unfriendly metal ions such as nickel might be stressful stimuli to antigen-presenting cells, macrophages and dendritic cells, and that those stress signals might be delivered to NK cells through the interaction between NKG2D and NKG2D ligands, which are upregulated upon various kinds of stresses on dendritic cells (Kim et al., 2004). We tried to find any kind of activation of dendritic cells in response to nickel, but we could not find any significant evidences of upregulation of activationrelated molecules in a macrophage cell line, RAW264.7 , or splenic dendritic cells upon nickel stimuli (data not shown). To check the role of NKG2D in the NK cell responsiveness to nickel, we performed the ELISPOT assay in the RAG-1-deficient and

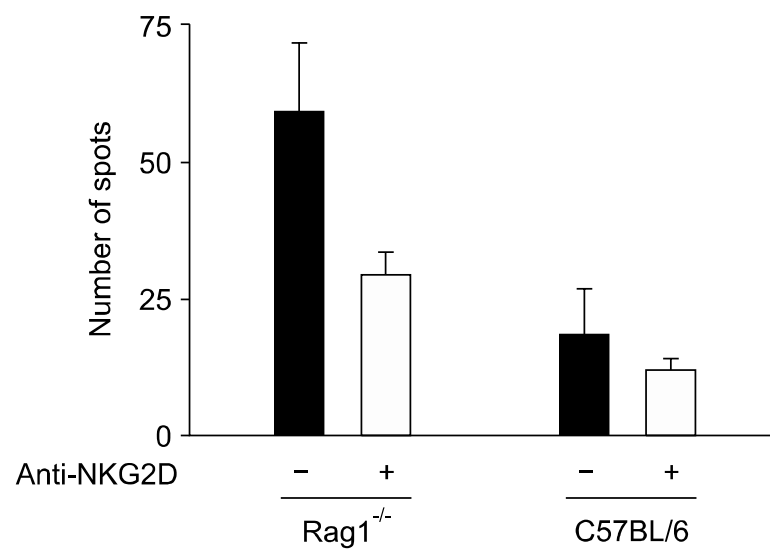

Figure 5. Reduction in the number of nickel-reactive IFN- $\gamma$-secreting cells by the NKG2D blockage. ELISPOT analyses were performed with splenocytes from RAG-1-deficient and wild type mice in the presence or absence of antibody to NKG2D, a major NK cell activating receptor.

wild type mice with or without the addition of anti-NKG2D antibody, which blocked NKG2D on NK cells (Figure 5). Treatment of anti-NKG2D antibody significantly reduced the number of nickelreactive IFN- $\gamma$-secreting cells in both RAG-1deficient and wild type mice. These results suggest that NKG2D may be at least a pathway of NK cell activation in the immune response to nickel. 


\section{Discussion}

Metal ions such as $\mathrm{Ni}^{2+}, \mathrm{Co}^{2+}, \mathrm{Cu}^{2+}$, or $\mathrm{Cr}^{3+}$ are haptens with a high immunogenic potential, as contact dermatitis caused by ionic metals occurs in about $10 \sim 25 \%$ of human population (Basketter et al., 1993; Hegewald et al., 2005). Among several metal ions, $\mathrm{Ni}^{2+}$ represents the most common occupational as well as public contact allergen, with up to $10 \%$ skin test positivity among general populations in clinical studies (von Blomberg-van der Flier et al., 1987; Nielsen et al., 2002). The responses of lymphocytes against metals are being increasingly recognized in many clinical situations, especially with the use of metallic biomaterials embedded in the body (Park et al., 2005). The immunological mechanism underlying the immune response against metal ions is thought to be a kind of Th1 type immune response that elicit a delayed type hypersensitivity reaction (Loh and Fraser, 2003; Martin, 2004). Then questions addressed are how nickel-specific $T$ cells can be generated and why they differentiate into the Th1 cells in metal hypersensitivity patients.

Besides binding conventional peptide antigens, $T$ cell receptors can specifically recognize peptides with modifications, which include phosphorylation (Zarling et al., 2000), glycosylation (Haurum et al., 1999), and association with metal ions (Budinger and Hertl, 2000). Metal-specific T cells may recognize a preformed complex of metal in association with $\mathrm{MHC}$ and bound peptide. In the case of nickel, several nickel-specific T cell clones were described and the basis of nickel recognition by some of them was analyzed. One of those $\mathrm{T}$ cell clones recognized $\mathrm{Ni}^{2+}$ in the context of HLA-DR52c, but it required unknown specific peptide generated in $B$ cells (Lu et al., 2003). Another clone recognized $\mathrm{Ni}^{2+}$ very promiscuously with a variety of $\mathrm{MHC}$ class II molecules containing the histidine amino acid residue at the position of 81 (Gamerdinger et al., 2003). Furthermore, its $\mathrm{Ni}^{2+}$ recognition did not require specific peptides, but this type of antigenic recognition was different from that of superantigen recognition by $\mathrm{T}$ cell receptor $\beta$ chain in that this $\mathrm{Ni}^{2+}$ recognition was coordinated by two essential amino acid residues in the CDR1 and CDR3 region of the $\mathrm{T}$ cell receptor $\alpha$ chain (McKay, 2001; Lu et al., 2003). In any cases, the frequency of nickelspecific $T$ cells appears to be similar to that of given peptide-specific $T$ cells and expansion of nickelspecific cells appears to require previous exposure to the nickel conjugated with $\mathrm{MHC}$ or antigenic peptide.

To understand the nickel responsiveness, critical nickel-binding proteins need to be elucidated. Al- though nickel is used for normal biological functions in some microbes, nickel has no known normal biological functions in vertebrates. However, nickel is a transition metal that forms coordination complexes with histidine, aspartate or glutamate residues, having a potential to influence the functions of many proteins. The nature of the proteins that associate with the nickel ions and activate the immune system is important to understand the pathogenesis of nickel hypersensitivity. In the biological fluid, $\mathrm{Ni}^{2+}$ ions are associated with proteins such as albumin (Thierse et al., 2004) and may be released or transferred to other proteins including immunoregulatory molecules such as $\mathrm{MHC}$. To the best of our knowledge, the $\mathrm{Ni}^{2+}$ - derivatized $\mathrm{MHC}$ is so far the only molecule that can activate the immune system as described above. The molecular entity to activate NK cells are not known yet, but we discuss here some possible molecular mechanisms for NK cell activation by nickel. The first hypothesis we tested was that nickel ions may activate dendritic cells or macrophages in an unknown stress-sensor pathway and that the stress may activate NK cells through the NKG2D receptor (Kim et al., 2006). With our hands, we could not observe any activation of macrophages and dendritic cells by the treatment with nickel ions. The second is that $\mathrm{Ni}^{2+}$ - derivatized $\mathrm{MHC}$ may also activate NK cells directly. In this case, the modification of MHC may occur extracellularly, and it may activate NK cells through the NK cell recognition of modified $\mathrm{MHC}$ molecules by activating NK receptors and/or loss of recognition of normal MHC molecules by inhibitory NK receptors (Sambrook and Beck, 2007; Lanier, 2008). The third may be a possibility of other cell surface proteins that associate with nickel ions and activate the activating NK receptors. Our results that the blockade of NKG2D reduced the number of nickelresponsive IFN- $\gamma$-secreting cells do not favor any one of above possibilities, but confirms that NK cells are participating in the response.

In summary, we observed the innate immune response to nickel ions by NK cells. The nickelresponsive IFN- $\gamma$ secretion by mouse splenic NK cells was rapid and involved the NKG2D receptor. We do not think that the nickel hypersensitivity could develop only through the innate response to nickel ions in the absence of adaptive immunity by nickel-specific $\mathrm{T}$ cells although there are reports showing a contact hypersensitivity that is dependent on NK cells and independent of $T$ and $B$ cells (O'Leary J et al., 2006). IFN- $\gamma$ secreted by activated NK cells may activate dendritic cells, resulting in the provision of costimulatory signals for $\mathrm{T}$ cells. Once nickel-responsive $\mathrm{T}$ cells are induced partly by acti- 
vated dendritic cells after initial exposure to nickel and later participate in the local reaction, they may induce a classical delayed type hypersensitivity response. We think that nickel challenge itself may be a weak stimulus and not sufficient to trigger the full activation of naive nickel- specific $T$ cells and hypothesize that other environmental stimuli such as other pollutants and concomitant microorganisms may provide stronger costimulatory signals to trigger the nickel-responsive $\mathrm{T}$ cell immune response fully and clinical nickel allergy.

\section{Methods}

\section{Mice}

C57BL/6 mice and Rag1-deficient mice (C57BL/6 background) were purchased from Orient Bio (Sungnam, Korea) and Jackson Laboratory (Bar Harbor, ME), respectively. Rag $1^{-/-}$mice were housed and bred in the specific pathogen-free facility. Mice were used at 6-8 weeks of age. All procedures were approved and guided by the institutional animal committee at Sungkyunkwan University School of Medicine.

\section{In vitro nickel stimulation and ELISPOT assay}

Wells of MultiScreen-IP plates (Millipore, Billerica, MA) were coated with $50 \mu \mathrm{l}$ either one of capture rat antibodies dissolved in PBS that were specific for mouse IFN- $\gamma$ (100 $\mu \mathrm{g} / \mathrm{ml})$, IL-2 $(100 \mu \mathrm{g} / \mathrm{ml})$ or IL-4 $(100 \mu \mathrm{g} / \mathrm{ml})$. After incubation overnight at $4^{\circ} \mathrm{C}$, unbound antibody was removed by three times of washing with PBS. The coated wells were blocked with 1\% BSA fraction V (Sigma-Aldrich, St. Louis, $\mathrm{MO})$. After $2 \mathrm{~h}$ at room temperature, the blocking medium was discarded and wells were washed three times with PBS. Then $1 \times 10^{6}$ mouse splenic cells were plated in complete RPMI 1640 medium (94\% RPMI $1640+5 \%$ FBS $+1 \%$ L-glutamine) within each well and treated with LPS, anti-CD3 antibody, or various concentrations of $\mathrm{NiSO}_{4}$. RPMI 1640 was from BioWhittaker (Walkersville, MD); FBS from Gibco-Invitrogen (Carlsbad, CA). After $24 \mathrm{~h}$ of incubation at $37^{\circ} \mathrm{C}$ on $5 \% \mathrm{CO}_{2}$, wells were washed three times with PBS and three times with PBS $/ 0.05 \%$ Tween-20 to remove cells. To detect secreted cytokines, $50 \mu \mathrm{l}$ of 50 $\mu \mathrm{g} / \mathrm{ml}$ biotinylated detection antibody against mouse IFN- $\gamma$, IL-2, or IL-4 were added per well. After incubating overnight at $4^{\circ} \mathrm{C}$, the plates were washed three times with PBS $/ 0.05 \%$ Tween-20 and then incubated with streptavidinHRP in PBS/BSA/Tween for $2 \mathrm{~h}$ at room temp. The spots were developed by using AEC (Pierce Pharmaceuticals, Denmark) development solution and the reaction was stopped by washing plates with tap water. Spots were counted by using Immunospot S4 Pro Analyzer (Cellular Technology Ltd., Cleveland, OH). All antibodies for ELISPOT were purchased from BD Biosciences (San Jose, CA).

\section{Nickel sensitization, NK cell depletion, and flow cytometric analysis}

To sensitize mice to nickel, mice were intraperitoneally injected with $300 \mu \mathrm{l}$ of $10 \mu \mathrm{M} \mathrm{NiSO}{ }_{4}$ mixed with $300 \mu \mathrm{l}$ alum (Inject Alum, Pierce). 2 or 4 weeks later after injection, mouse splenocytes were used for the ELISPOT analyses. For depletion of NK cells in other experiments, mice were injected intraperitoneally with $25 \mu \mathrm{g}$ anti-NK1.1 (BioLegend, San Diego, CA) in $300 \mu$ PBS on days 0,3 and 6 . On day 8 , mice were sacrificed and spleens were harvested. Depletion of NK cells was confirmed by flow cytometric analysis. The conditions for the ELISPOT analysis were same as described above.

Anti-NK1.1-biotin, anti-CD49b-biotin, streptavidin-PE and streptavidin-FITC (BD Biosciences) were used for flow cytometric analyses. To analyze splenocytes, red blood cells were lysed by incubation in lysis buffer containing 17 $\mathrm{mM}$ Tris and $140 \mathrm{mM} \mathrm{NH}_{4} \mathrm{Cl}$ for $5 \mathrm{~min}$ at room temperature. Cells were washed with PBS, counted and incubated for 30 min at $4^{\circ} \mathrm{C}$ with antibodies and washed three times with PBS containing $2 \%$ FBS and $0.05 \%$ sodium azide. Data acquisition and analysis was done on FACSCalibur (BD Biosciences) using CellQuest software.

\section{Statistical analysis}

For statistical analysis, Microsoft Excel 2003 (Microsoft Corporation, Redmond, WA) and SPSS version 14 (SPSS Inc., Chicago, IL) were used. $P<0.05$ was considered statistically significant for all tests. Additional post-tests for ANOVA were performed only when ANOVA showed significant difference.

\section{Acknowledgements}

This work was supported by a grant from (01-PJ3-PG601GN12-0001) from the 2001 Good Health R \& D Project, Ministry of Health and Welfare, Republic of Korea. K.H. gratefully acknowledges a financial support from the BK 21 Project of the Korean Ministry of Education.

\section{References}

Akira S, Uematsu S, Takeuchi O. Pathogen recognition and innate immunity. Cell 2006;124:783-801

Artik S, Haarhuis K, Wu X, Begerow J, Gleichmann E. Tolerance to nickel: oral nickel administration induces a high frequency of anergic $\mathrm{T}$ cells with persistent suppressor activity. J Immunol 2001;167:6794-803

Basketter DA, Briatico-Vangosa G, Kaestner W, Lally C, Bontinck WJ. Nickel, cobalt and chromium in consumer products: a role in allergic contact dermatitis? Contact Dermatitis 1993;28:15-25

Budinger L, Hertl M. Immunologic mechanisms in hypersensitivity reactions to metal ions: an overview. Allergy 2000;55:108-15

de Waard-van der Spek FB, Oranje AP. Patch Tests in children with suspected allergic contact dermatitis: $A$ prospective study and review of the literature. Dermatology 2008

Gamerdinger K, Moulon C, Karp DR, Van Bergen J, Koning 
F, Wild D, Pflugfelder U, Weltzien HU. A new type of metal recognition by human T cells: contact residues for peptideindependent bridging of $\mathrm{T}$ cell receptor and major histocompatibility complex by nickel. J Exp Med 2003;197: 1345-53

Goodnow CC, Sprent J, de St Groth BF, Vinuesa CG. Cellular and genetic mechanisms of self tolerance and autoimmunity. Nature 2005;435:590-7

Hallab NJ, Anderson S, Stafford T, Glant T, Jacobs JJ. Lymphocyte responses in patients with total hip arthroplasty. J Orthop Res 2005;23:384-91

Haurum JS, Hoier IB, Arsequell G, Neisig A, Valencia G, Zeuthen J, Neefjes J, Elliott T. Presentation of cytosolic glycosylated peptides by human class I major histocompatibility complex molecules in vivo. J Exp Med 1999;190: $145-50$

Hawiger D, Masilamani RF, Bettelli E, Kuchroo VK, Nussenzweig MC. Immunological unresponsiveness characterized by increased expression of CD5 on peripheral T cells induced by dendritic cells in vivo. Immunity 2004;20: 695-705

Hegewald J, Uter W, Pfahlberg A, Geier J, Schnuch A. A multifactorial analysis of concurrent patch-test reactions to nickel, cobalt, and chromate. Allergy 2005;60:372-8

Ishii N, Sugita Y, Nakajima H, Tanaka S, Askenase PW. Elicitation of nickel sulfate $\left(\mathrm{NiSO}_{4}\right)$-specific delayed-type hypersensitivity requires early-occurring and early-acting, $\mathrm{NiSO}_{4}$-specific DTH-initiating cells with an unusual mixed phenotype for an antigen-specific cell. Cell Immunol 1995;161:244-55

Kapsenberg ML, Res P, Bos JD, Schootemijer A, Teunissen MB, Van Schooten W. Nickel-specific T lymphocyte clones derived from allergic nickel-contact dermatitis lesions in man: heterogeneity based on requirement of dendritic antigenpresenting cell subsets. Eur J Immunol 1987;17:861-5

Kim A, Noh YW, Kim KD, Jang YS, Choe YK, Lim JS. Activated natural killer cell-mediated immunity is required for the inhibition of tumor metastasis by dendritic cell vaccination. Exp Mol Med 2004;36:428-43

Kim JY, Son YO, Park SW, Bae JH, Chung JS, Kim HH, Chung BS, Kim SH, Kang CD. Increase of NKG2D ligands and sensitivity to NK cell-mediated cytotoxicity of tumor cells by heat shock and ionizing radiation. Exp Mol Med 2006;38: 474-84

Kroczek RA, Mages HW, Hutloff A. Emerging paradigms of T-cell co-stimulation. Curr Opin Immunol 2004;16:321-7

Lanier LL. Up on the tightrope: natural killer cell activation and inhibition. Nat Immunol 2008;9:495-502

Loh J, Fraser J. Metal-derivatized major histocompatibility complex: zeroing in on contact hypersensitivity. J Exp Med 2003;197:549-52

Lu L, Vollmer J, Moulon C, Weltzien HU, Marrack P, Kappler $\mathrm{J}$. Components of the ligand for a $\mathrm{Ni}^{++}$reactive human $\mathrm{T}$ cell clone. J Exp Med 2003;197:567-74
Martin SF. T lymphocyte-mediated immune responses to chemical haptens and metal ions: implications for allergic and autoimmune disease. Int Arch Allergy Immunol 2004; 134:186-98

Matzinger P. The danger model: a renewed sense of self. Science 2002;296:301-5

McKay DM. Bacterial superantigens: provocateurs of gut dysfunction and inflammation? Trends Immunol 2001;22: 497-501

Mortz CG, Lauritsen JM, Bindslev-Jensen C, Andersen KE. Prevalence of atopic dermatitis, asthma, allergic rhinitis, and hand and contact dermatitis in adolescents. The Odense adolescence cohort study on atopic diseases and dermatitis. Br J Dermatol 2001;144:523-32

Nielsen NH, Linneberg A, Menne T, Madsen F, Frolund L, Dirksen A, Jorgensen $T$. Incidence of allergic contact sensitization in Danish adults between 1990 and 1998; the Copenhagen Allergy Study, Denmark. Br J Dermatol 2002; 147:487-92

O'Leary J G, Goodarzi M, Drayton DL, von Andrian UH. T celland $B$ cell-independent adaptive immunity mediated by natural killer cells. Nat Immunol 2006;7:507-16

Park YS, Moon YW, Lim SJ, Yang JM, Ahn G, Choi YL. Early osteolysis following second-generation metal-on-metal hip replacement. J Bone Joint Surg Am 2005;87:1515-21

Saglam AM, Baysal V, Ceylan AM. Nickel and cobalt hypersensitivity reaction before and after orthodontic therapy in children. J Contemp Dent Pract 2004;5:79-90

Sambrook JG, Beck S. Evolutionary vignettes of natural killer cell receptors. Curr Opin Immunol 2007;19:553-60

Sato N, Kinbara M, Kuroishi T, Kimura K, Iwakura Y, Ohtsu $\mathrm{H}$, Sugawara S, Endo Y. Lipopolysaccharide promotes and augments metal allergies in mice, dependent on innate immunity and histidine decarboxylase. Clin Exp Allergy 2007;37:743-51

Schafer T, Bohler E, Ruhdorfer S, Weigl L, Wessner D, Filipiak B, Wichmann HE, Ring J. Epidemiology of contact allergy in adults. Allergy 2001;56:1192-6

Sebastiani S, Albanesi C, Nasorri F, Girolomoni G, Cavani A. Nickel-specific CD4(+) and CD8(+) T cells display distinct migratory responses to chemokines produced during allergic contact dermatitis. J Invest Dermatol 2002;118: 1052-8

Silvennoinen-Kassinen S, Poikonen K, Ikaheimo I. Characterization of nickel-specific T cell clones. Scand J Immunol 1991;33:429-34

Thierse HJ, Moulon C, Allespach Y, Zimmermann B, Doetze A, Kuppig S, Wild D, Herberg F, Weltzien HU. Metal-protein complex-mediated transport and delivery of $\mathrm{Ni}^{2+}$ to TCR/MHC contact sites in nickel-specific human $\mathrm{T}$ cell activation. J Immunol 2004;172:1926-34

von Blomberg-van der Flier M, van der Burg CK, Pos O, van de Plassche-Boers EM, Bruynzeel DP, Garotta G, Scheper $R J$. In vitro studies in nickel allergy: diagnostic value of a dual 
parameter analysis. J Invest Dermatol 1987;88:362-8

Zarling AL, Ficarro SB, White FM, Shabanowitz J, Hunt DF Engelhard VH. Phosphorylated peptides are naturally processed and presented by major histocompatibility complex class I molecules in vivo. J Exp Med 2000;192: 1755-62
Zug KA, McGinley-Smith D, Warshaw EM, Taylor JS, Rietschel RL, Maibach HI, Belsito DV, Fowler JFJ, Storrs FJ, DeLeo VA, Marks JGJ, Mathias CG, Pratt MD, Sasseville D. Contact allergy in children referred for patch testing: North American Contact Dermatitis Group data, 2001-2004. Arch Dermatol 2008;144:1329-36 